\title{
Still in Hospital
}

National Cancer Institute

\section{Source}

National Cancer Institute. Still in Hospital. NCI Thesaurus. Code C154477.

An indication that a patient remains in an in-patient hospital. 